\title{
LIBERTAD RELIGIOSA
}

\section{RELIGIOUS FREEDOM}

\section{Jorge PreCht PiZARro*}

Un fallo reciente que no acogió un recurso de protección en contra del arzobispo de Santiago en un caso de abandono de la fe religiosa católica ${ }^{1}$, da pie para analizar, brevemente, la interesante visión con que la Ilustrísima Corte de Apelaciones de Santiago se aproxima, aún hoy, al tratamiento del fenómeno religioso en su dimensión de derecho fundamental consagrado en nuestra Carta Magna; aproximación que resulta reñida con el sistema de interpretación que debe utilizarse al abordar la protección que nuestro sistema jurídico le da a este derecho.

El recurrente interpone recurso de protección contra el entonces arzobispo de Santiago, don Francisco Javier Errázuriz Ossa, por cuanto a través de una omisión arbitraria e ilegal se le habría privado y perturbado el libre ejercicio de su libertad de conciencia, manifestación de todas las creencias y el ejercicio libre de todos los cultos, derecho garantizado en el No 6 del Art. $19^{2}$ de la Carta Fundamental.

El recurrente señala que fue bautizado en la fe católica en una decisión ajena a su voluntad y que, al pasar de los años, llegó a la convicción de no seguir siendo miembro de la

* Licenciado en Ciencias Jurídicas y Sociales, Universidad de Chile; Magíster en Derecho Internacional y Comparado, Vrije Universiteit van Brussel; Doctor en Derecho, Université Catholique de Louvain; profesor de Derecho Administrativo, Pontificia Universidad Católica de Chile. Email: jorgeprecht@gmail.com.

${ }^{1}$ Sentencia de fecha 29 de noviembre de 2010, Rol No 7112-2010, Pronunciada por la Tercera Sala de la Ilustrísima Corte de Apelaciones de Santiago.

2 Artículo 19.- La Constitución asegura a todas las personas: $6^{\circ}$ La libertad de conciencia, la manifestación de todas las creencias y el ejercicio libre de todos los cultos que no se opongan a la moral, a las buenas costumbres o al orden público. [...]
Iglesia, decisión que habría sido comunicada a la recurrida, solicitando ser desafectado de la Iglesia. Menciona que las razones de la solicitud son sus prácticas sexuales, estimando que la Iglesia se ha convertido en una institución castigadora, abusiva y desprestigiada en su ejercicio ético.

Se agrega a la causa un informe del cardenal Errázuriz señalando algunas perplejidades que surgen de la acción constitucional, como el hecho de que el compareciente ha quedado en libertad total de adscribirse a otra confesión religiosa o que habría fijado de manera unilateral un plazo para la respuesta a su intención de desafectación, cuando estas materias están reguladas por el propio Derecho de la Iglesia, cuya vigencia es reconocida por el Estado de Chile.

Sin entrar al fondo del litigio, parece de la mayor trascendencia analizar el considerando tercero:

"Que el recurso de protección de garantías constitucionales se encuentra regulado en el artículo 20 de la Constitución Politica de la República, señalando de manera expresa cuáles garantías de las señaladas en el artículo 19 se encuentran resguardadas por esta acción, entre las que no se cuentan la contenida en el artículo $19 N^{\circ} 6$ de la Carta Fundamental".

Ahora bien, el texto oficial de la Constitución de 1980 contempla y ha contemplado siempre el artículo 19 No 6 como derecho cuyo ejercicio legítimo debe ser protegido por la acción constitucional de protección. Lo mismo establecía el capítulo II De los recursos procesales, artículo $2^{\circ}$, del Acta Constitucional No 3 (D. L. 1552, 13-9-1976).

Si haciendo un ingente esfuerzo académico por salvar la postura de una de las Salas 
de la Ilustrísima Corte de Apelaciones de Santiago, se dijera que en parte alguna de la Constitución se habla de "libertad religiosa", sino solo de "ejercicio libre de todos los cultos" y de la "manifestación de todas las creencias", no es menos cierto que se habla de "libertad de conciencia".

La "libertad de conciencia" debe ser interpretada como hoy por hoy lo hacen los Pactos vigentes en Derechos Humanos. Ella comprende la libertad de conciencia del creyente y la libertad de conciencia del no creyente. Los Derechos Humanos deben ser promovidos y respetados por todos los órganos del Estado de Chile, según el artículo $5^{\circ}$ inciso $2^{\circ}$ de la Constitución.

Frente a este olvido jurídico, quizá sea más prudente pensar que una golondrina no hace verano, y ante la pregunta de cómo pudo producirse tamaño error, deberíamos decir junto a los teólogos: "hay misterios que son insondables". 